\title{
Rehabilitasi Pasca Covid-19 Menjadi Kunci Untuk Meningkatkan Kesehatan Pada Masyarakat
}

Sekar Wulan Apriliasari ${ }^{1}$

${ }^{1}$ Universitas Bhakti Kencana

E-mail: 191ff03090@bku.ac.id

Raihany Sholihatul ${ }^{2}$

${ }^{2}$ Universitas Bhakti Kencana

E-mail: raihany290891@gmail.com

Ida Lisni ${ }^{3}$

${ }^{3}$ Universitas Bhakti Kencana

E-mail: ida.lisni@bku.ac.id

\author{
Aulia Nurfazri Istiqomah ${ }^{4}$ \\ ${ }^{4}$ Universitas Bhakti Kencana \\ E-mail: Aulia.nurfazri@bku.ac.id \\ Wahyu Wahdana ${ }^{5}$ \\ ${ }^{5}$ Universitas Bhakti Kencana \\ E-mail: wahyuwahdana@gmail.com
}

Article History:

Received: 2021-09-23

Revised: 2021-12-30

Accepted:2022-01-25
Abstract: The pandemic due to Covid-19 can cause problems in Indonesia, especially on health problems that are mostly experienced by people who located in the Sukarindik Village area, Tasikmalaya City. Therefore, in order to solve the problem that occurred in Sukarindik Village, Tasikmalaya, carried out the 2021 Thematic PPM KKN activity program through post-Covid-19 physical rehabilitation measures in the form of breathing exercises, relaxation, exercise, exercise and jogging. The implementation of these activities is carried out online with the method of implementing webinar activities using the Zoom application. The results showed that the people of Sukarindik Village would carry out regular exercise every week to maintain physical fitness, improve heart 
Keywords : Physical rehabilitation, Covid-19, Aerobics. and lung function. In conclusion, education related to post-Covid-19 physical rehabilitation for the community is important. Because it can accelerate the healing of symptoms exposed to Covid-19, improve the quality of daily activities and improve health in the Sukarindik Village Community.
Riwayat Artikel :

Diajukan: 23-09-2021

Diperbaiki: 30-12-2021

Diterima: 25-01-2022
Abstrak: Pandemi akibat Covid-19 bisa menyebabkan masalah di Indonesia terutama pada masalah Kesehatan yang sebagian besar dialami oleh masyarakat yang berada di daerah Kelurahan Sukarindik Kota Tasikmalaya. Permasalahan yang muncul di Keluran Sukarindik yaitu Masyarakat dikelurahan sukarindik kurang prokes $5 \mathrm{M}$, Masyarakat yang sudah terpapar di kelurahan sukarindik masih mengalami gejala fisik pasca covid seperti mudah lelah, batuk dan nafas pendek, Partisipasi masyarakat kurang termotivasi melakukan olahraga rutin, Masyarakat kurang mengatahui aktivitas fisik apa saja yang harus dilakukan pasca Covid-19. Oleh karena itu, untuk memecahkan masalah yang terjadi di Kelurahan Sukarindik Tasikmalaya dilakukan program kegiatan KKN PPM Tematik 2021. Beberapa Tindakan yang harus dilakukan kepada masyarakat salah satunya Tindakan rehabilitasi yang bertujuan untuk Mengurangi gejala, Mengurangi komplikasi, Meminimalkan kecacatan, Meningkatkan kualitas Kesehatan, Mencegah berkurangnya fungsi tubuh, Mempercepat penyembuhan. melalui tindakan rehabilitasi fisik pasca 
Covid-19 yang berupa Latihan pernafasan, relaksasi, workout, senam dan jogging. Pelaksanaan kegiatan tersebut dilakukan secara daring dengan metode pelaksanaan kegiatan webinar yang menggunakan aplikasi zoom. Hasil penelitian menunjukkan bahwa masyarakat Kelurahan Sukarindik akan melaksanakan senam rutin setiap minggunya untuk menjaga kebugaran fisik, meningkatkan fungsi jantung dan paru-paru. Kesimpulannya edukasi terkait rehabilitasi fisik pasca Covid-19 terhadap masyarakat itu penting. Sebab dapat mempercepat penyembuhan gejala yang terpapar Covid19, meningkatkan kualitas beraktivitas

Kata kunci : Rehabilitasi fisik, Covid-19, Senam aerobik. sehari-hari dan meningkatkan kesehatan pada Masyarakat Kelurahan Sukarindik.

\section{Pendahuluan}

Pandemi Coronavirus Disease 2019 (Covid-19) yang terjadi saat ini, mengharuskan setiap orang mengurangi aktivitas diluar ruangan dan melakukan karantina mandiri sehingga memengaruhi gaya hidup terutama sendentary lifestyle (Mattioli et al.,2020). Hal ini akan berpengaruh besar bagi Kesehatan apalagi gejala yang dialami oleh masyarakat yang terpapar seperti mudah lelah, nafas pendek, dan demam akan berdampak buruk jika tidak di lakukan aktivitas fisik. Aktivitas fisik merupakan salah satu faktor penting bagi Kesehatan dan kesejahteraan (Blake et al., 2017). Kurangnya aktivitas fisik merupakan salah satu masalah terbesar kesehatan dunia di abad ke-21 ini. Meskipun banyak orang yang mengetahui manfaat fisik dan psikologi dari aktivitas fisik namun masih terdapat beberapa faktor yang menghambat dan menyebabkan rendahnya aktivitas fisik di kalangan dewasa (Chang et al.,2016). Pada pandemi Covid-19 banyak hal yang dilakukan dengan mengonsumsi makanan bergizi (seperti buah, sayur, ikan), meminum vitamin, jamu serta obat-obatan untuk meningkatkan kesehatan dan tidak lupa untuk selalu mematuhi protokol kesehatan 5M. 
Rehabilitasi merupakan intervensi penting bagi pasien klinis sekaligus penyembuhannya. Dan pentingnya rehabilitas fisik ini untuk masyarakat sehat agar terhindar virus Covid-19, karena aktivitas fisik ini akan meningkatkan imun yang dapat melawan virus masuk kedalam tubuh dan terhindar terpaparnya virus Covid-19. (Zhao H-M.et al.,2020).

Terkait tempat analisis kegiatan KKN ini di daerah Tasikmalaya Tepatnya Jalan raya Sukarindik, Kecamatan Bungursari Kota Tasikmalaya dengan jumlah masyarakat 11.000 jiwa dan 51 RT dan 11 RW. Dijelaskan pada data yang kita dapat kasus penyebaran Covid-19 dikelurahan Sukarindik pada Tanggal 27 Juli 2021 mencapai 269 kasus positif Covid-19 , 46 kasus aktif, 212 kasus sembuh, 42 orang melakukan isolasi mandiri, 4 orang dirujuk dan dirawat di rumah sakit dan 4 orang meninggal (Ketua Lurah, Bapak Suryaman, S.IP).

Dengan data yang kami dapatkan kondisi daerah RT/RW kelurahan Sukarindik berada di Zona Kuning. Kasus penuluran Covid-19 disebabkan oleh penuluran lokal, wilayah menetapkan protokol kesehatan masyarakat mematuhi protokol kesehatan dan masyarakat dihimbau untuk tidak melakukan pertemuan, kerumunan dan keramaian.

kasus penyebaran Covid-19 di kelurahan sukarindik pada tanggal 27 juli 2021 mencapai 269 kasus positif covid 19, 46 kasus aktif ,212 kasus sembuh , 42 melakukan isolasi mandiri ,4 orang dirujuk dan dirawat di rumah sakit ,dan 4 kasus meninggal. Dari wawancara kepada petugas kelurahan menjelaskan masyarakat di kelurahan Sukarindik salah satunya tidak mematuhi Prokes 5M yang disebabkan oleh pekerjaan masyarakat setiap harinya berkerumun, adapula yang tidak memakai masker dan tidak rutin melakukan olahraga fisik.

Berdasarkan hasil Analisa situasi ditemukan permasalahan pada Mitra (Kelurahan Sukarindik) dalam pencegahan penuluran Covid-19 yaitu :

1. Masyarakat di kelurahan Sukarindik kurang Prokres $5 \mathrm{M}$ dalam aktivitas sehari-hari ini menyebabkan angka penyebaran Covid-19 di kelurahan Sukarindik Meningkat.

2. Masyarakat yang sudah terpapar di kelurahan Sukarindik masih mengalami gejala fisik pasca covid seperti mudah lelah, batuk dan nafas pendek.

3. Partisipasi masyarakat kurang termotivasi melakukan olahraga rutin.

4. Masyarakat kurang mengetahui aktivitas fisik apa saja yang harus dilakukan pasca Covid19. 
5. Puskesmas belum mengadakan kegiatan rehabilitasi fisik pasca Covid-19.

Dari pemaparan yang sudah dijelaskan diatas hasil analisis Kelompok 37 KKN PPM Tematik 2021 Universitas Bhakti Kencana memiliki program terkait Rehabilitasi Pasca Covid19 yang bertujuan agar masyarakat bisa memahami pentingnya menjaga kesehatan fisik serta dapat menerapkan kegiatan fisik secara rutin. Tindakan Rehabilitasi untuk masyarakat yang sudah terpapar Covid-19 dan Tindakan preventif bagi masyarakat yang belum terpapar Covid19 , kegiatan fisik yang bisa dilakukan berupa : Latihan nafas dalam, relaksasi, work out senam kebugaran , jogging serta pemanasan dan pendinginan. Manfaat dari rehabilitasi fisik pasca Covid-19 yaitu Mengurangi Gejala, mengurangi komplikasi, mengurangi kecacatan , meningkatkan kualitas kesehatan, mencegah berkurangnya fungsi tubuh, dan mempercepat penyembuhan. Rehabilitasi selama penanganan akut Covid-19 harus dipertimbangkan jika memungkinkan dan aman serta dapat mencakup nutrisi , jalan napas, postur tubuh, teknik pembersihan, suplementasi oksigen, Latihan pernapasan, peregangan, terapi manual dan aktivitas fisik. Meningkatkan kemungkinan kecacatan jangka pancang, rehabilitasi dapat di pertimbangkan pada semua pasien yang dirawat di rumah sakit maupun isolasi Mandiri Covid19 (Paruba et al., 2021).

Solusi yang diharapkan untuk setiap kegiatan dalam rangka menyelesaikan permasalahan yang dihadapi adalah sebagai berikut :

1. Masyarakat di Kelurahan Sukarindik kurang Prokes $5 \mathrm{M}$ dalam aktivitas sehari-hari ini menyebabkan angka penyebaran Covid-19 di Kelurahan Sukarindik meningkat. Upaya untuk menyelesaikan masalah tersebut dengan cara mengedukasi betapa pentingnya prokes 5M menggunakan media Poster.

2. Masyarakat yang sudah terpapar di Kelurahan Sukarindik masih mengalami gejala fisik pasca Covid-19 seperti mudah lelah, batuk dan nafas pendek. Upaya untuk mengetahui masalah tersebut dengan cara melakukan skrining (G.form) kesehatan pada pasien yang sudah terpapar pasca Covid-19.

3. Partisipasi masyarakat kurang termotivasi melakukan olahraga rutin , upaya untuk menyelesaikan masalah tersebut dengan cara mengedukasi tentang Rehabilitasi Fisik Pasca Covid-19 melalui Webinar, Mengunggah Video di Media massa seperti IG, Youtube. 
4. Masyarakat kurang mengetahui aktivitas fisik apa saja yang harus dilakukan pasca Covid19, upaya untuk menyelesaikan masalah tersebut dengan cara mengedukasi tentang Rehabilitasi Fisik Pasca Covid-19 melalui Webinar, Mengunggah Video di Media massa seperti IG, Youtube.

5. Puskesmas belum mengadakan kegiatan rehabilitasi fisik pasca Covid-19, upaya untuk menyelesaikan masalah tersebut dengan cara bekerja sama dengan puskesmas membuat program Rehabilitasi pasca Covid-19 secara online.

\section{Metode}

Pelaksanaan Kegiatan Webinar dengan Judul Rehabilitasi pasca Covid-19 kunci untuk meningkatkan kesehatan pada masyarakat dilakukan menggunakan Aplikasi ZOOM yang dilaksanakan pada Hari Minggu 8 Agustus 2021. Untuk kegiatan ini melibatkan Masyarakat, Tokoh masyarakat, Puskesmas, Posyandu, Posbindu Sukarindik dengan Pemateri Ibu Hj. Sri Mulyati, S.Kep., Ners.,M.Kep dan juga melibatkan masyarakat yang berusia muda hingga dewasa kelurahan Sukarindik Tasikmalaya.

Tahapan Pelaksanaan kegiatan Pengabdian kepada Masyarakat ini dilaksanakan dengan beberapa tahapan yaitu :

A. Tahapan persiapan

a. Menentukan mitra, memilih Kelurahan Sukarindik Tasikmalaya tingkat resiko penyebaran sedikit, dekat dengan kampus cabang, Mitra melakukan senam aerobic rutin setiap minggu sebelum terjadinya pandemic Covid-19.

b. Menganalisis situasi merupakan tahap pengumpulan data, mengidentifikasi masalah kondisi umum masyarakat Kelurahan Sukarindik Tasikmalaya sebelum merancang dan merencanakan program.

c. Membuat dan membagikan Instrument Google Form berisi pretest kepada masyarakat di Kelurahan Sukarindik Tasikmalaya dari rentang usia remaja hingga tua ,anak sekolah hingga masyarakat yang telah bekerja yang dapat mengakses google form berisikan kuesioner yang telah dianalisa permasalahannya oleh kelompok kami. Pengisian kuesioner dilakukan sebelum 3 minggu kegiatan penyuluhan diberikan. Kegiatan mengisi kuesioner pretest dilaksanakan pada tanggal 18 Juli 2021. 
d. Mengidentifikasi masalah menentukan dan menjelaskan apa masalah yang di temukan di Kelurahan Sukarindik Tasikmalaya.

e. Membuat perencanaan Program yang sesuai dengan solusi.

f. Membuat proposal dan pengajuan proposal.

g. Menentukan susunan Kepanitiaan agar masing-masing anggota kelompok terlibat dalam kepanitiaan sehingga munculnya rasa tanggung jawab dan kebersamaan.

h. Merancang topik kegiatan.

i. Membuat susunan acara untuk membuat acara lebih tersusun, lebih rapi dan teratur.

j. Menentukan waktu dan tempat kegiatan.

k. Membuat video edukasi yang bertujuan untuk membuat masyarakat semakin mengetahui dan paham tentang protokol kesehatan.

I. Menghubungi narasumber dan moderator serta meminta kesediannya untuk mengisi kegiatan webinar.

m. Koordinator dengan Tim Kelompok KKN, Dosen pembimbing dan mitra agar terjalin Kerjasama yang baik.

n. Mempersiapkan alat prasarana.

o. Melakukan publikasi webinar kepada peserta.

p. Mempersiapkan link absensi/link kuisoner berupa posttest dan untuk evaluasi kegiatan.

B. Tahapan Pelaksanaan

a. Mengingatkan peserta $\mathrm{H}-1$ sebelum pelaksanaan kegiatan.

b. Melakukan dokumentasi.

c. Pemberian sertifikat dan plakat.

C. Tahapan Evaluasi

a. Merekap daftar hadir peserta.

b. Rekap pertanyaan dan jawaban yang diberikan selama kegiatan webinar berlangsung.

c. Link kuisoner evaluasi sekaligus posttest kegiatan webinar diberikan kepada peserta sesaat setelah kegiatan webinar selesai berlangsung. 
d. Membuat LPJ untuk menjabarkan seluruh proses kegiatan operasional secara rinci dan jelas, terdapat juga penjelasan masalah yang dihadapi selama proses untuk menjadi pembelajaran pada kegiatan selanjutnya.

\section{Hasil dan Diskusi}

\section{Pemberian kuesioner Pretest dan Posttest}

Pretest sebagai kegiatan menguji/mengetahui pengetahuan masyarakat kelurahan Sukarindik ,Tasikmalaya terhadap materi yang akan disampaikan yaitu pengetahuan tentang Rehabilitasi Pasca Covid-19 dan kegiatan Fisik untuk meningkatkan kebugaran masyarakat. Pretest dan posttest ini terdiri dari 12 (dua belas) pertanyaaan terkait Rehabilitasi Pasca Covid-19 dan kegiatan Fisik untuk meningkatkan kebugaran masyarakat dan diikuti oleh 120 orang masyarakat kelurahan sukarindik. Skor yang diperoleh dari pretes adalah rentang 0.0-100.0 pada tabel berikut:

\section{Hasil Pretest}

Table 1. Nilai rata-rata pengisian kuesioner pretest

\begin{tabular}{lcc}
\hline Point benar & Jumlah & Prosentase (\%) \\
\hline$<5$ & 15 & 12,5 \\
$>5$ sampai 7 & 52 & 43,33 \\
8 sampai 11 & 46 & 38,33 \\
$=12$ & 7 & 5,84 \\
Total & 120 & 100 \\
\hline
\end{tabular}

Dari data yang didapat pada table 1 menunjukkan nilai rata-rata pengisian kuesioner pretest dengan hasil menjawab benar $<5$ soal sebanyak 15 orang persentase $12,5 \%$ ,menjawab benar $>5$ sampai 7 soal sebanyak 52 orang persentase $43,33 \%$, menjawab 8 sampai 11 soal sebanyak 46 persentase 38,33\% , dan menjawab 12 soal benar sebanyak 7 orang persentase $5,84 \%$.

Dari data yang diperoleh diharapkan dengan diadakannya kegiatan penyuluhan dapat meningkatkan pengetahuan masyarakat kelurahan Sukarindik, Tasikmalaya terkait Rehabilitasi Pasca Covid-19 untuk Meningkatkan Kesehatan Pada Masyarakat dan menerapkannya dikehidupan sehari-hari. 
Hasil Posttest

Table 2. Nilai rata-rata pengisian kuesioner posttest

\begin{tabular}{lcc}
\hline Point benar & Jumlah & Prosentase (\%) \\
\hline$<5$ & 0 & 0 \\
$>5$ sampai 7 & 2 & 1,67 \\
8 sampai 11 & 47 & 39,17 \\
$=12$ & 71 & 59,16 \\
Total & 120 & 100 \\
\hline
\end{tabular}

Dari data yang didapat pada table 2 menunjukkan nilai rata-rata pengisian kuesioner posttest pengetahuan masyarakat kelurahan Sukarindik, Tasikmalaya meningkat dengan hasil menjawab benar $<5$ soal sebanyak 0 orang persentase $0 \%$,menjawab benar $>5$ sampai 7 soal sebanyak 2 orang persentase 1,67\%, menjawab 8 sampai 11 soal sebanyak 47 persentase $39,17 \%$, dan menjawab 12 soal benar sebanyak 71 orang persentase $59,16 \%$. dapat disimpulkan hasil kegiatan penyuluhan ini dapat memberikan pengetahuan tambahan bagi masyarakat kelurahan Sukarindik ,Tasikmalaya. Peningkatan hasil yang didapat menandakan masyarakat tidak kesulitan dalam mengerjakan kuesioner posttest dan mendapatkan pengetahuan terkait Rehabilitasi Pasca COVID-19 setelah acara diselenggarakan pada tanggal 8 Agustus 2021 melalui zoom meeting, acara selengkapnya dapat diakses channel youtube: https://youtu.be/Iv1qGwJ UDO .

\section{Kegiatan Penyuluhan}

Pada pandemi Covid-19 banyak hal yang dilakukan dengan mengonsumsi makanan bergizi (seperti buah, sayur, ikan ), meminum vitamin, jamu serta obat-batan untuk meningkatkan kesehatan di masa pandemic Covid-19. Tidak lupa masyarakat harus mematuhi protokol kesehatan $5 \mathrm{M}$.

Pada gambar 1, gambar 2, gambar 3 dan gambar 4 dapat dilihat proses kegiatan Penyuluhan berupa Poster Protokol Kesehatan Pencegahan dan Pengendalian Covid-19 di daerah Kelurahan Sukarindik Kota Tasikmalaya , bertujuan untuk membangun kesadaran dalam diri masyarakat di daerah Kelurahan Sukarindik Kota Tasikmalaya. Informasi poster 
JURNAL ASTA

Abdi Masyarakat Kita

Vol. 02 No. 01, Januari 2022

Pencegahan dan Pengendalian Covid-19 dapat diakses di Instagram @rebitcov_37 yang telah diakses lebih dari 120 Followers yang berasal dari kelurahan sukarindik pada saat pelaksanaan kegiatan, dan dapat di akses dalam grup kelurahan sukarindik untuk tingkat lanjut penyuluhan kami di kelurahan.

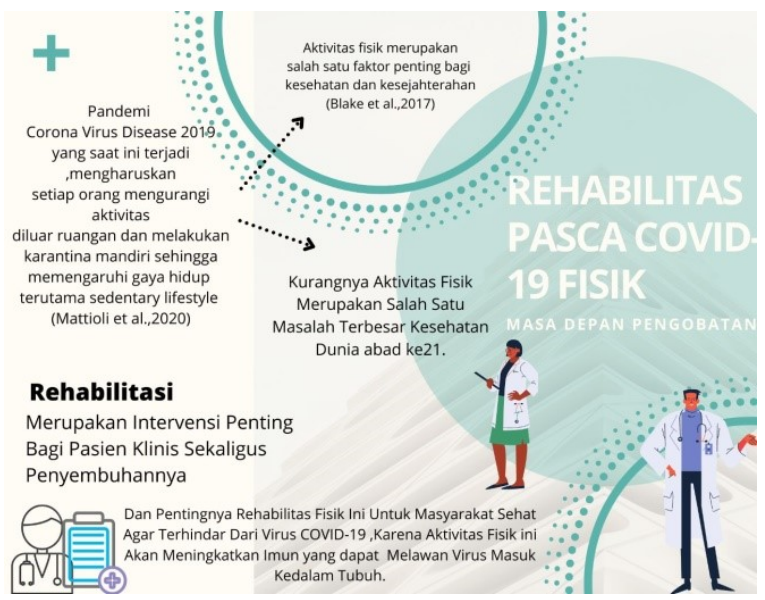

Gambar 1. Penyuluhan Rehabilitas

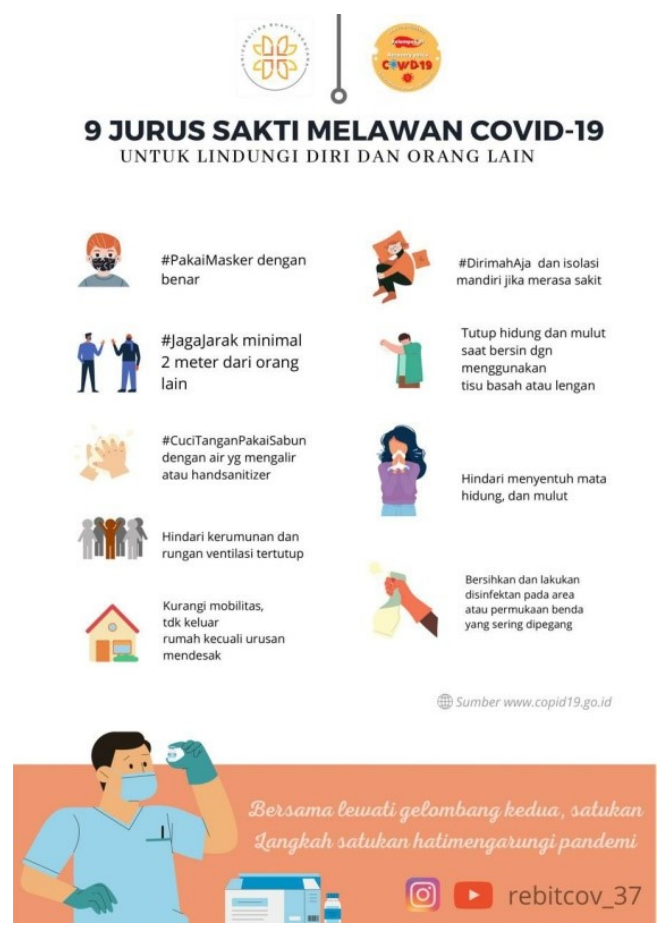

Gambar 3. Penyuluhan Jurus Jitu Melawan Covid-19

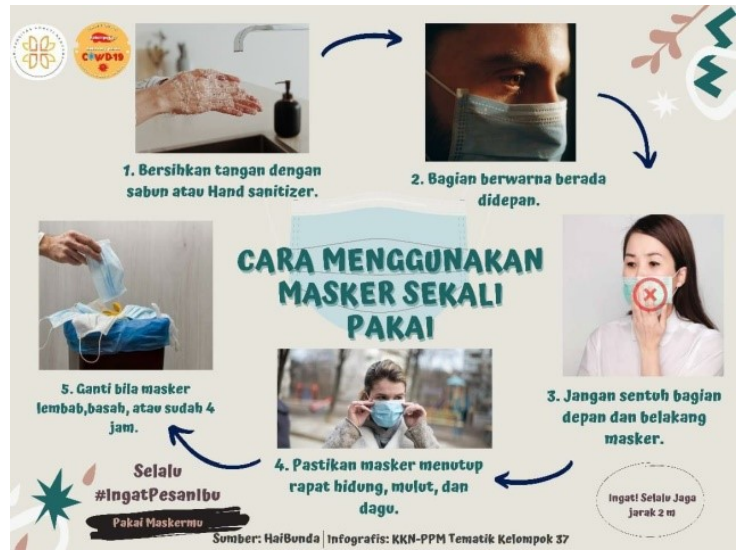

Gambar 2. Cara Menggunakan Masker

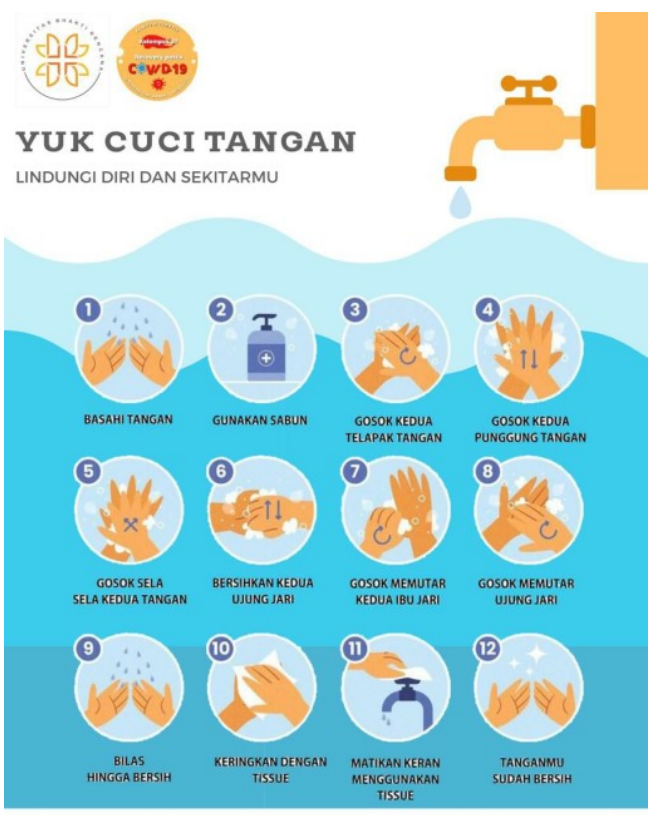

(0) rebitcov-37

Æsumber. www.kpai.co.id

Gambar 4. Penyuluhan Cara Cuci Tangan 
Kegiatan dilaksanakan melalui beberapa metode diantaranya pembuatan Poster sebanyak 4 buah Poster Penyuluhan dapat diakses melalui Instagram @rebitcov_37 yang berisikan rangkaian acara, Video senam aerobik , wawancara masyarakat dan aparat desa serta Kegiatan Webinar dengan Judul Rehabilitasi pasca Covid-19 kunci untuk meningkatkan kesehatan pada masyarakat dilakukan menggunakan Aplikasi ZOOM yang dilaksanakan pada Hari Minggu 8 Agustus 2021 yang dihadiri oleh 120 partisipan dapat diakses channel youtube: https://youtu.be/Iv1qGwJ UDO
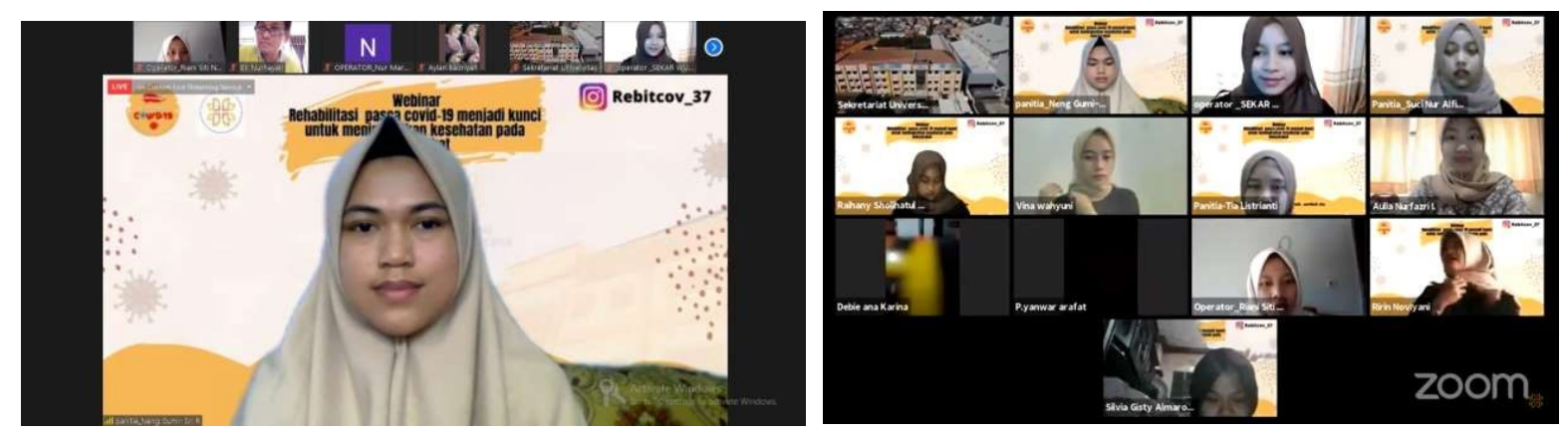

Gambar 5. Pelaksanaan kegiatan webinar

Dengan hasil dan diskusi Didapatkan masyarakat menerapkan Prokes, Masyarakat memiliki pengetahuan bagaimana aktivitas fisik pasca Covid-19, Masyarakat Kelurahan Sukarindik akan melaksanakan senam rutin setiap minggunya untuk menjaga kebugaran fisik, meningkatkan fungsi jantung dan paru-paru, mempercepat penyembuhan gejala masyarakat yang terpapar Covid-19 serta Tindakan pencegahan agar tidak terpapar Covid-19, meningkatkan kualitas beraktivitas sehari-hari dan meningkatkan kesehatan pada Masyarakat Kelurahan Sukarindik.

\section{Pemantauan dan Evaluasi}

Dari hasil wawancara setelah kegiatan penyuluhan kepada beberapa petugas kelurahan dan beberapa RW di kelurahan Sukarindik menghasilkan bahwa dari beberapa RT/RW Sukarindik sudah menetapkan protokol kesehatan dan relative aman serta gejala yang dialami tergolong ringan karena masyarakat telah melakukan rutin aktivitas olahraga yang mampu membantu meningkatkan imunitas tubuh , dan ada beberapa yang tidak merasakan gejala. Dan Setiap RT/RW di Kelurahan Sukarindik melakukan strategi yaitu melakukan senam 
JURNAL ASTA

Abdi Masyarakat Kita

Vol. 02 No. 01, Januari 2022

aerobic rutin yang dilakukan setiap 1 minggu sekali di RW 03 yang dipimpin oleh kader puskesmas dan pelatih senam yang bergantian dalam mempimpin senam di desa sukarindik ,Pembentukkan Satgas Covid-19 dan membagikan masker gratis untuk masyarakat agar masyarakat ikut serta mencegah penuluran Covid-19.

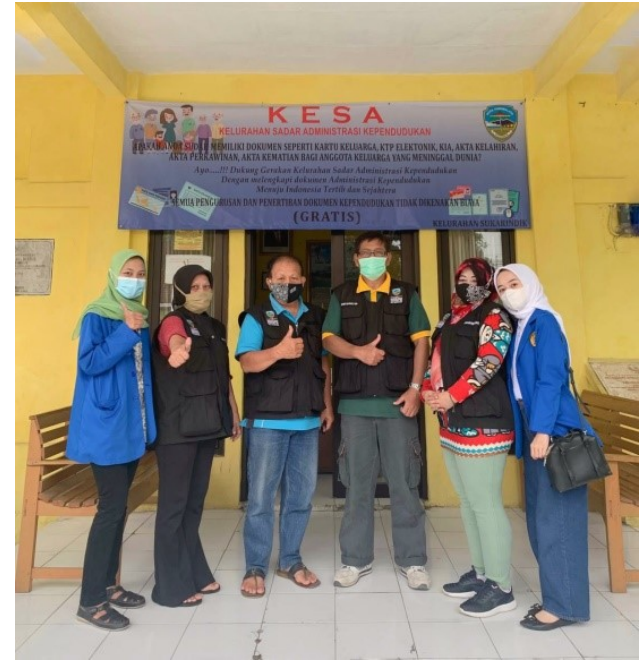

Gambar 6. kerja sama bersama kelurahan

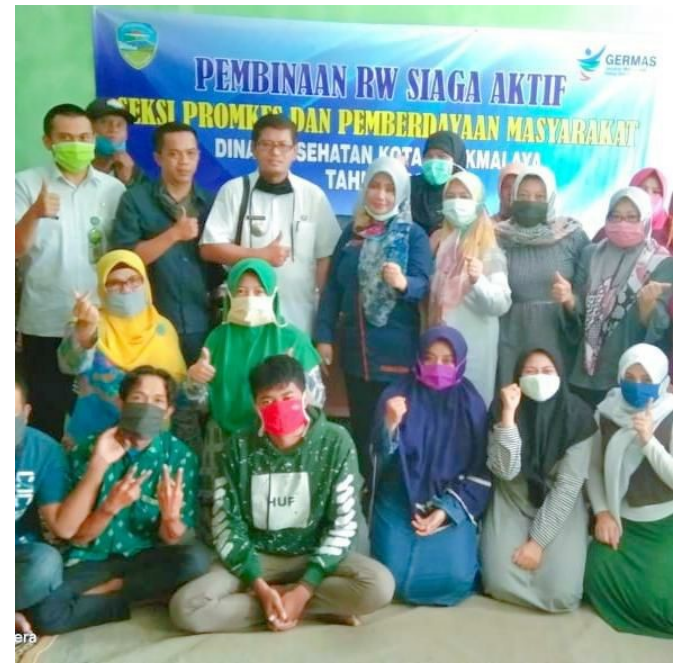

Gambar 7.Pembinaan Seksi Promkes

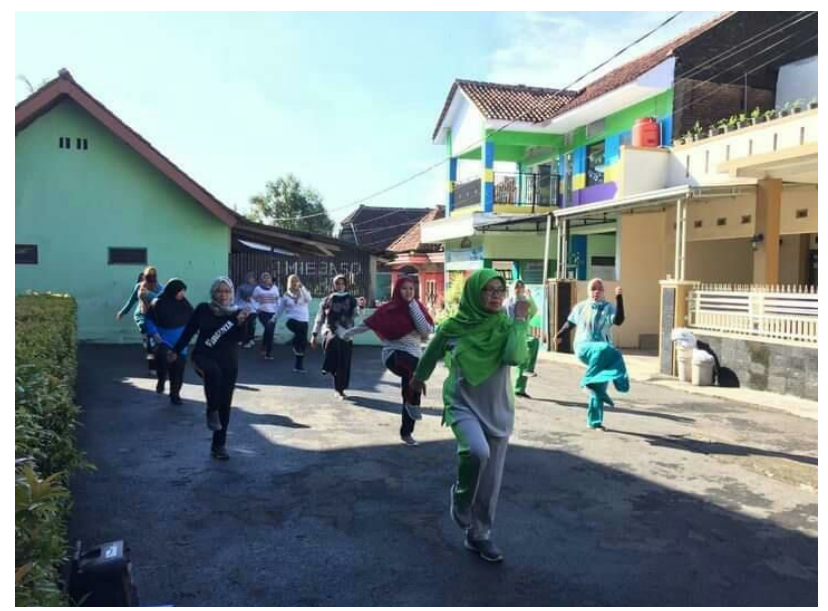

Gambar 8. Aktivitas rehabilitasi senam aerobic dikelurahan

\section{Deskripsi Perubahan yang Akan Terjadi di Masyarakat}

Kegiatan ini diharapkan dapat menjadi sumber informasi yang mampu meningkatkan pengetahuan masyarakat tentang Rehabilitas Pasca Covid-19 untuk Meningkatkan Kesehatan pada masyarakat kelurahan Sukarindik, Tasimalaya . Rangkaian kegiatan ini senam ,wawancara masyarakat didokumentasikan dengan baik, dan telah dipublikasikan 
melalui youtube: https://youtube.com/channel/UC3ns04C-r_yBUX7Us1DAZ4w , kegiatan Penyuluhan pada youtube: https://youtu.be/IvlqGwJ_UD0 dan selengkapnya bisa diakses pada Instagram : @rebitcov_37.Publikasi juga dilakukan melalui media masa yaitu Koran Tribbun Jawa Barat: https://jabar.tribunnews.com/2021/08/15/pengabdian-kepadamasyarakat-universitas-bhakti-kencana yang telah diterbitkan pada Minggu, 15 Agustus 2021.

\section{Kesimpulan}

Edukasi ini dikemas melalui kegiatan webinar dengan teknik komunikasi efektif dua arah seperti diskusi aktif agar Masyarakat Sukarindik dapat memahami Covid-19 secara umum dari pengertian, penyebab, gejala dan rehabilitasi pasca Covid-19. Masyarakat dapat menerapkan perubahan sikap dengan rutin berolahraga, menambah pengetahuan kepada masyarakat aktivitas terhadap rehabilitasi fisik, masyarakat dapat mengetahui aktivitas fisik apa saja yang dilakukan, dan masyarakat bisa menerapkan gerakan praktis yang dilakukan dirumah tanpa harus berkurumun namun membuat badan menjadi fit, dapat pulih dengan cepat dan melakukan aktivitas rutin lainnya seperti normal tanpa adanya gejala Covid-19 yang mengganggu.

\section{Ucapan Terimakasih}

Penulis mengucapkan terimakasih pada seluruh Akademi Universitas Bhakti Kencana, Dosen Pembimbing, Panitia Pelaksanaan KKN Tematik 2021 terutama kelompok 37 KKN Tematik serta Mitra Kelurahan Sukarindik atas dukungannya dalam skema pengabdian masyarakat sehingga kegiatan edukasi ini dapat terlaksana dengan baik.

\section{Daftar Pustaka}

Isbaniyah F, \& dkk.(2020). Pedoman Kesiapan siagaan menghadapi infeksi noverl coronavirus2 (2019-nCov). Jakarta.

Kementerian Kesehatan Republik Indonesia, Direktorat Jenderal Pencegahan dan pengendalian Penyakit; Medik pada pasien Coronavirus Disease 2019. Medical Scope Journal (MSJ). Volume 3(1),83-89. 
JURNAL ASTA

Abdi Masyarakat Kita

Vol. 02 No. 01, Januari 2022

Paruba Mercy. C.K, Gessal Jourdy dan Lampah Christopher.(2021).

Respati T., \& dkk.(2018). Buku Ajar Ilmu kesehatan masyarakat: Bandung. P2U Universitas Islam Bandung

Subuh M., dkk.(2020). Pedoman penaganan cepat medis dan Kesehatan Masyarakat : Jakarta.

Zhao H-M, Xie, Y-X, Wang C. (2020). Recommendations for Respiratory Rehabilitation of COVID-19 in Adults: Chinese Medical Journal.133(13):1595-1602 